\title{
Performance of chick pea under the influence of gibberellic acid and oxygenated peptone during germination
}

\author{
Utkarsha Thakare $^{1 *}$, Neelam Patil ${ }^{1}$, Nutan Malpathak ${ }^{2}$ \\ ${ }^{1}$ P. G. Research Center, Department of Botany, Tuljaram Chaturchand College, Baramati, India; \\ ${ }^{2}$ Department of Botany, University of Pune, Pune, India. \\ Email: *ug.thakare@gmail.com, neelampatil_123@yahoo.com; mpathak@unipune.ac.in
}

Received 10 November 2010; revised 1 December 2010; accepted 7 December 2010

\begin{abstract}
The experiments were carried out at the Post Graduate Research Center, to study the influence of Gibberellic Acid (50 ppm) and Oxygenated Peptone (1\% aqueous solution) on chick pea (Cicer arietinum $\mathrm{L}$. cv. Vijay) during germination by giving pre-sowing soaking treatment for 6 hours using petriplate method. Both the treatments enhanced the germination process. GA treatment was useful to increase shoot length, mobilization efficiency, emergence index, speed of germination and co-efficient of germination while oxygenated peptone showed an upper hand in root length, shoot/root ratio, biomass and vigour index. GA led to comparatively more synthesis of nucleic acids while oxygenated peptone showed more increase in total carbohydrates and soluble protein content. However, the activity of enzymes like amylase, catalase and protease showed upper hand with oxygenated peptone as compared to GA. In fact GA is costlier and can not be used in organic farming as it enters metabolic pathways of plant and alters them. Hence the use of oxygenated peptone is recommended being less expensive and usable under organic farming condition as it does not enter the plant metabolic pathways and yet brings about significant positive effect.
\end{abstract}

Keywords: Chick Pea; Enzyme Activity; Germination; Gibberellic Acid; Organic Farming; Oxygenated Peptone

\section{INTRODUCTION}

The life cycle of plant starts with seed germination, which is associated with degradation and mobilization of the reserves accumulated during seed maturation. Germination starts with water intake and activation of cytoplasm which are energy related processes requiring oxygen for respiration. The energy released during respiration is utilized for growth. Bewley and Black [1] stated that during germination, initially there is a sharp increase in oxygen consumption, which can be attributed to the activation and hydration of mitochondrial enzymes involved in citric acid cycle and electron transport chain. According to Taiz and Zeiger [2], the rate of germination increases with oxygen supply. Oxygen also takes part in various oxygenation reactions of cell metabolism and transport of plant growth regulators (PGRs). The PGRs have been found to play a central role in the integration of the responses expressed by plants [3]. PGRs may also enhance germination [4]. Gibberellic acid is reported to increase percentage germination and seedling growth [5]. Pre-sowing treatment, also called as seed priming gives osmo-conditioning effect. It is the physiological method which improves seed performance and provides faster and synchronized germination [6]. Such treatment is found to improve germination and seedling establishment. Seed priming has been successfully demonstrated to improve germination and emergence on seeds of many crops [7]. Harris et al. [8] showed that under normal condition, hydro-priming is effective for germination and later growth of maize, rice and chickpea. Caseiro et al. [9] found that hydro-priming was the most effective method for improving seed germination of onion. Nascimento [10] remarked that primed seeds had higher germination compared to unprimed seeds. He further added that priming may be used to improve germination performance. Oxygenated peptone is found to enhance germination of seeds of tomato, brinjal and chilli [11]. Role of gibberellic acid in seed germination is also well established. Exogenous GA stimulates amylase activity. Aleurone layer of endosperm is sensitive to GA. GA also causes release of enzymes amylase and protease. These enzymes participate in the break down of stored starch to simple sugars. These sugars are then translocated to growing embryo where they provide energy for growth. Thus both oxygen and GA enhance seed germination.

There is no work carried out to compare the germina- 
tion responses of seed to GA and oxygen supply. So in present investigation, the germination studies are carried out in chick pea by giving pre-soaking treatment of GA and oxygenated peptone (a source of oxygen). Oxygenated peptone (with $100 \mathrm{mg} / \mathrm{g}$ oxygen, $650 \mathrm{mg} / \mathrm{g}$ peptone and $250 \mathrm{mg} / \mathrm{g}$ inert filler compound) has been found to induce enhancement in germination processes in solanaceous fruit vegetables like tomato, brinjal and chilli by seed priming treatment [11]. Wijte and Gallagher [12] found that no plumule or root growth occurred under anoxia in the early stages of development of salt marsh plants. So both GA and oxygen supply seem to be the important factors governing the process of germination. In the present investigation, an attempt is made to compare the germination performance of chickpea seeds under the influence of priming treatment with GA and with oxygenated peptone. This comparison is needed for two reasons, first GA is costlier than oxygenated peptone and second GA can not be used under organic farming conditions as it enters the metabolic pathway of plant and alters it while oxygenated peptone supplies $\mathrm{O}_{2}$ and peptone. So it is to be found out whether oxygenated peptone can replace GA priming treatment which will lead to less costly and healthier food, grown in organic way.

\section{MATERIALS AND METHODS}

The seeds of chick pea (Cicer arietinum L. cv. Vijay) were surface sterilized with 0.05 percent $\mathrm{HgCI}_{2}$ for 1 min., washed under running water and rinsed with distilled water. The surface sterilized seeds were soaked separately in 50 ppm gibberellic acid and 1\% aqueous solution of oxygenated peptone for 6 hours. The seeds kept in distilled water for 6 hours worked as control. Then the seeds were allowed to germinate in petriplates using Whatman No.1 filter paper soaked with $10 \mathrm{ml}$. of distilled water. Five petriplates with 20 seeds per replicate were used for each treatment. Hand sorted seeds were used to eliminate broken and small seeds. Number of seeds germinated was noted daily.

Various parameters like germination percentage, shoot length, root length, shoot/root ratio and biomass were studied on 6 DAS using routine method. Emergence of radical was considered as indicator of germination. Vigour Index (VI) was calculated according to the method suggested by Abdul Baki and Anderson [13]. Emergence Index (EI) was calculated by the method suggested by Baskin [14]. Speed of germination (SG) was calculated by the formula given by Maguire [15]. Coefficient of Velocity of Germination (CVG) was calculated as per the formula given by Kotowski [16]. Mobilization Efficiency (ME) of reserve food material present in seed during germination was calculated by the formula by
Srivastava and Sareen [17]. Biochemical constituents were analyzed on 8 DAS, using methods proposed by Lowry et al. [18] for proteins, Sadasivam and Manickam [19] for total carbohydrates, DNA and RNA. The enzyme activity was studied on 10 DAS. The enzyme activity of amylase (EC 3.2.1.1) and catalase (EC 1.11.1.6), was scored by the method of Sadasivam and Manickam [19] ands that of protease (EC 3.4.2.2) by the method of Penner and Ashton [20].

\section{RESULTS AND DISCUSSION}

The effect of pre-soaking treatment of GA and oxygenated peptone on morphological parameters of germinating seeds of chickpea is exhibited in Table 1. All the seeds showed $100 \%$ germination 6 days after treatment. Both the treatments brought about enhancement in shoot length, root length, shoot/root ratio and biomass. GA plays direct role in stem elongation [21]. Hence, as expected, treatment of GA led to more enhancements in shoot length (92.47\%) than that by oxygenated peptone (52.65\%). This is supported by observation of Jamil and Rha [22] who reported maximum increase in shoot length and root length under the treatment of gibberellic acid. GA treatment seems to support shoot growth rather than root growth by exhibiting $92.47 \%$ increase in shoot length and just $10.02 \%$ increase in root length. But, increase in root length is more pronounced under oxygenated peptone treatment (28.08\%) than under GA treatment (10.02\%). Obviously, oxygenated peptone exhibited more shoot/root ratio (9.83\%) than GA (9.01\%). It seems that oxygenated peptone supports the development of root system than that of shoot system during germination by supplying soluble nitrogen and oxygen so that seedling is well established with extended root system. This is supported by Cherif et al. [23], who observed that high oxygen treatment resulted in an increase in plant growth, as measured by shoot and root weights. Root and shoot weights were about the same in nitrogen treated and controls. They further added that hypoxia led to membrane instability. Here it should be noted that root and shoot length are the most important parameters because roots are in direct contact in soil and absorb water from soil and shoots supply it to the rest of the plant. This is reflected in the biochemical constituents of germinating seeds with significant increase in total carbohydrates and soluble proteins by $20.43 \%$ and $68.11 \%$ respectively using oxygenated peptone treatment. At the same time, oxygenated peptone exhibited more Vigour Index (VI) because this parameter depends on germination percentage, root length and shoot length. However, the level of mobilization efficiency (ME) was shown better by GA (27.34\%) than by oxygenated peptone (16.01\%). Incidentally, the Emergence Index (EI), Speed 
Table 1. Effect of pre-sowing soaking treatment of GA and oxygenated peptone on seeds of Chick pea (Cicer arietinum L. cv. Vijay) on morphological parameters of germination (6 DAS).

\begin{tabular}{|c|c|c|c|c|c|c|}
\hline \multirow[b]{2}{*}{ Sr. No. } & \multirow{2}{*}{ Parameters } & \multicolumn{2}{|l|}{ Control } & \multicolumn{2}{|c|}{ Treatments } & \multirow[b]{2}{*}{ Increase (\%) } \\
\hline & & Distilled water & Gibberellic acid & Increase (\%) & Oxygenated peptone & \\
\hline 1. & Shoot length (cm.) & $2.27 \pm 0.65$ & $4.35 * \pm 1.32$ & 92.47 & $3.45 * \pm 1.08$ & 52.65 \\
\hline 2. & Root length (cm.) & $9.98 \pm 1.90$ & $10.98 * \pm 2.95$ & 10.02 & $12.7^{* *} \pm 1.19$ & 28.05 \\
\hline 3. & Shoot / root ratio & $1.22 \pm 2.16$ & $1.33 * \pm 1.59$ & 9.01 & $1.34^{*} \pm 1.82$ & 9.83 \\
\hline 4. & Biomass (gm.) & $4.98 \pm 0.48$ & $5.18 * \pm 0.46$ & 4.01 & $5.19^{*} \pm 0.46$ & 4.21 \\
\hline 5. & Vigour Index (VI) & $1074 \pm 60.3$ & $1339 * 335.4$ & 24.67 & $1406^{*} \pm 375.8$ & 30.91 \\
\hline 6. & $\begin{array}{l}\text { Mobilization } \\
\text { Efficiency } \\
\text { (ME) }\end{array}$ & $12.36 \pm 0.18$ & $15.74 * * \pm 0.35$ & 27.34 & $14.34^{*} \pm 0.22$ & 16.01 \\
\hline 7. & $\begin{array}{l}\text { Emergence Index } \\
\text { (EI) }\end{array}$ & $17.16 \pm 1.15$ & $17.72 * \pm 1.01$ & 3.2 & $16.83^{\mathrm{ns}} \pm 0.32$ & -1.92 \\
\hline 8. & $\begin{array}{c}\text { Speed of Germina- } \\
\text { tion (SG) }\end{array}$ & $5.30 \pm 0.35$ & $5.61^{* *} \pm 0.01$ & 5.84 & $3.26^{\mathrm{ns}} \pm 0.20$ & -38.49 \\
\hline 9. & $\begin{array}{l}\text { Co-efficient of } \\
\text { velocity of germi- } \\
\text { nation (CVG) }\end{array}$ & $40.07 \pm 10.2$ & $41.66^{*} \pm 14.4$ & 3.96 & $29.81^{\mathrm{ns}} \pm 4.16$ & -25.60 \\
\hline
\end{tabular}

of Germination (SG) and Coefficient of Velocity of germination (CVG) showed positive values in GA treated seeds and negative values in seeds treated with oxygenated peptone.

Table 2 shows the effect of pre-soaking treatment of GA and oxygenated peptone on biochemical constituents in germinating seeds of chickpea (8DAS). Both the treatments led to increase in total carbohydrates and soluble proteins. Oxygenated peptone increased the amount of soluble proteins significantly (68.11\%) due to supply of soluble nitrogen in the form of peptone in addition to oxygen. Nucleic acids like DNA and RNA also showed increase under the influence of both treatments, with GA showing an upper hand. The activity of enzymes amylase, catalase and protease increased under both the treatments as compared to control with oxygenated peptone showing an upper hand. Catalase is an oxidative enzyme. The increased activities of amylase and protease are well correlated with the enhanced quantities of carbohydrates and proteins. Contrary to this, Ashton [24] and Misra and Kar [25] recorded that enhanced protease activity resulted in concomitant decline in storage and enzymatic protein. Muhyaddin and Wiebe [26] suggested that the enzymes are activated with an accompanying mobilization of reserve material ending in transport of reserve material in the embryo and thus stronger seedlings are obtain as a result of embryo growth. Penner and Ashton [20] suggested that the embryonic axis, through the production of plant hormones controls the protein breakdown by regulating the synthesis of proteases in storage tissue of seeds. Oxygenated peptone treatment shows an upper hand for carbohydrate and protein contents well as enzyme activity as compared to GA in the present investigation which is significant.

Figure 1 projects the effect of the treatment of GA and oxygenated peptone on embryonal growth in chickpea seeds during germination. Both the treatments showed enhancement in morphological characters. Oxygenated peptone treatment resulted in more increase in root length while GA treatment showed upper hand in shoot length. But, it is clearly visible that even though shoot length was comparatively less under oxygenated peptone treatment condition, these shoots appeared more sturdy and vigorous with dark brown testa than the delicate, elongated shoots with light colored testa under GA treatment.

Seed germination is an important event in the life cycle of plant. This process determines survival of most plant species. Germination is a very complex process. A variety of factors including endogenous as well as environmental; influence seed germination. Ample supply of oxygen is needed during germination. Bewley and Black [1] observed that in maize, there was subsequent increase in oxygen consumption when incubated in water for $6 \mathrm{hr}$. from start of germination. This higher oxygen demand is due to increase in mitochondrial oxidation as 


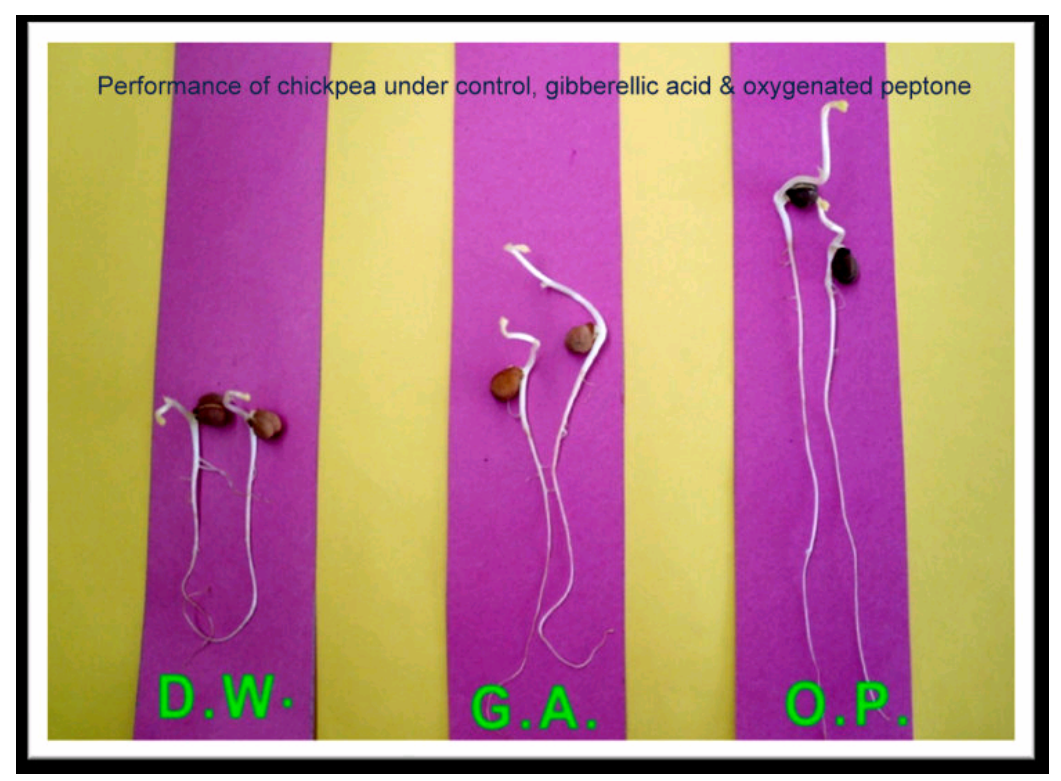

Figure 1. Germinating seeds of Cicer arietinum L. cv. Vijay under control, GA treatment and oxygenated peptone treatment.

Table 2. Effect of pre-sowing soaking treatment of GA and oxygenated peptone on biochemical constituents and enzyme activity of seeds of chick-pea (Cicer arietinum L. cv. Vijay) as on 6 DAS.

\begin{tabular}{|c|c|c|c|c|c|c|}
\hline \multirow[b]{2}{*}{ Sr. No } & \multirow[b]{2}{*}{ Parameters } & \multirow{2}{*}{$\begin{array}{c}\text { Control } \\
\text { Distilled } \\
\text { Water } \\
\end{array}$} & \multicolumn{4}{|c|}{ Treatments } \\
\hline & & & Gibberellic acid & Increase (\%) & Oxygenated peptone & Increase (\%) \\
\hline & $\begin{array}{l}\text { Biochemical con- } \\
\text { stituents }\end{array}$ & & & & & \\
\hline 1. & $\begin{array}{l}\text { Total carbohydrates } \\
\text { (mg / g FW.) }\end{array}$ & $233 \pm 4.24$ & $269 * \pm 4.2$ & 15.65 & $280 * \pm 11.3$ & 20.43 \\
\hline 2. & $\begin{array}{l}\text { Soluble proteins } \\
\text { (mg / g FW.) }\end{array}$ & $900 \pm 140.7$ & $950 * \pm 81.1$ & 5.5 & $1513^{* *} \pm 23.0$ & 68.11 \\
\hline 3. & $\begin{array}{c}\text { DNA } \\
\text { (mg/g FW.) }\end{array}$ & $0.37 \pm 0.15$ & $0.56^{*} \pm 0.02$ & 51.35 & $0.52^{* *} \pm 0.01$ & 40.54 \\
\hline 4. & $\begin{array}{c}\text { RNA } \\
\text { (mg/g FW.) }\end{array}$ & $1.6 \pm 0.03$ & $2.0^{*} \pm 0.16$ & 25 & $1.87^{*} \pm 0.04$ & 16.87 \\
\hline & Enzyme activity & & & & & \\
\hline 1. & $\begin{array}{c}\text { Amylase } \\
\text { (mg maltose / } 5 \mathrm{~min} / \mathrm{g} \\
\mathrm{FW})\end{array}$ & $10.1 \pm 0.1$ & $16.1^{*} \pm 1.9$ & $\mathbf{5 9 . 4 0}$ & $18.4^{*} \pm 1.5$ & 80.39 \\
\hline 2. & $\begin{array}{c}\text { Catalase } \\
\left(\mu \text { mole } \mathrm{H}_{2} \mathrm{O}_{2} / \mathrm{min} / \mathrm{g}\right. \\
\mathrm{FW})\end{array}$ & $1.86 \pm 0.51$ & $3.54 * \pm 0.30$ & 90.32 & $3.84 * \pm 0.27$ & 106 \\
\hline 3. & $\begin{array}{c}\text { Protease } \\
\text { ( } \mu \mathrm{g} \text { tyrosine } / \mathrm{hr} . \mathrm{mg} \\
\text { protein) }\end{array}$ & $0.10 \pm .005$ & $0.17^{*} \pm 0.01$ & 70 & $0.19 * \pm 0.001$ & 90 \\
\hline
\end{tabular}

Values are the mean of Five determinations \& Standard deviation ---- $( \pm)$ \& Significance at $1 \%$ level ---- $(* *)$ \& Significance at $5 \%$ level ---- $(*)$

a result of both repairs of mitochondria already existing within mature dry seeds and production of new mitochondria during germination. Ample supply of oxygen allows the operation of citric acid pathway liberating more energy per hexose molecule (38ATPs) and suppresses anaerobic pathway liberating less energy (8ATPs). Seed priming with oxygenated peptone gives the same advantage in the present investigation. Wil- lumsen and Roeber [27] noted that the low content of air in propagation substrates may restrict germination and initial growth of seedling in cabbage. An increase in germination and enhanced seedling vigour obviously lead to establishment of good and healthy crop stand leading to better productivity. The overall picture shows that the pre-soaking treatment of GA and oxygenated peptone brings about positive effect on germination of 
chickpea seeds. GA, being a hormone, enters the metabolic pathways, alters them and brings about the changes by activating protein synthesis. Oxygenated peptone supplies the oxygen, so that there is rapid conversion of complex reserve food into simpler substances and rapid rate of respiration so as to liberate more ATPs useful for growth process. Oxygenated peptone also supplies soluble nitrogen in the form of peptone which is useful for germination process. Thus, oxygenated peptone does not enter the metabolic pathways and yet brings about the positive changes. Oxygenated peptone can be used for organic farming [28] but GA can not be used as it alters metabolic pathways. Oxygenated peptone treatment is less costly than GA. So it can be concluded that pre-soaking treatment of both GA and oxygenated peptone are useful to enhance the germination process in chick pea and in addition oxygenated peptone treatment has an advantage of being included in organic farming.

\section{REFERENCES}

[1] Bewley, J.D. and Black, M. (1994) Cellular events during germination and seedling growth. In: Bewley, J.D. and Black, M., Eds., Seed Physiology of Development and Germination, Plenum Press, New York, 147-197.

[2] Taiz, L. and Zeiger, E. (2002) Plant physiology. 3rd Edition, Prima Publishing Corporation, New Delhi.

[3] Amzallag, G.N., Lener, H.R. and Poljackoff-Mayber, A. (1990) Exogenous ABA as a modulator of the response of sorghum to high salinity. Journal of Experimental Botany, 541, 1529-1534. doi:10.1093/jxb/41.12.1529

[4] Banyal, S. and Rai, V.K. (1983) Reversal of osmotic stress effects by gibberellic acid in Brassica campestris. Recovery of hypocotyls growth, protein and RNA levels in presence of GA, Physiologia Plantarum, 59, 111-114. doi:10.1111/j.1399-3054.1983.tb06580.X

[5] Kaur, S., Gupta, A.K. and Kaur, N. (1998) Gibberellic acid and kinetin partially reverse the effect of water stress on germination and seedling growth. Plant Growth Regulator, 25, 29-33.

[6] Siveritepe, H.O. and Dourado, A.M. (1995) The effect of priming treatment on the viability and accumulation of chromosomal damage in aged pea seeds. Annals of Botany, 75, 165-171. doi:10.1006/anbo.1995.1008

[7] Heydecker, W. and Coolbaer, P. (1977) Seed treatments for improved performance survey and attempted prognosis. Seed Science Technology, 5, 353-425.

[8] Harris, D., Joshi, A., Khan, P.A., Gothkar, P. and Sodhi, P.S. (1999) On-farm seed priming in semi-arid agriculture: Development and evolution in maize, rice and chickpea in India using participatory methods. Experimental Agriculture, 35, 15-29. doi:10.1017/S0014479799001027

[9] Caseiro, R., Bennett, M.A. and Marcos-Filho, J. (2004) Comparison of three priming techniques for onion seed lots differing in initial seed quality. Seed Science and Technology, 32, 365-375.

[10] Nascimento, W.M. (2005) Vegetable seed priming to improve germination at low temperature. Horticultura Brasileira, 23, 211-214.

[11] Patil, N.A., Chiatale, R.D. and Dhumal, K.N. (2008) Role of oxygenated peptone in enhancing germination of tomato, brinjal and chill. Indian Journal of Plant Physiology, 13, 137-142.

[12] Wijte, A.H.B.M. and Gallagher, J.L. (1996) Effect of oxygen availability and salinity on early life history stages of salt marsh plants. II. Early seedling development advantage of Spartina alterniflora and Phragmites australis (Poaceae). American Journal of Botany, 83, 1343-1350. doi: $10.2307 / 2446120$

[13] Baki, A. and Anderson, J.D. (1993) Vigour determination in soybean seed by multiple criteria. Crop Science, 3, 630-663.

[14] Baskin, C.C. (1969) GADA and seedling measurement as tests for seed quality. Proceedings of Seedsmen, Mississippi State University, 59-69.

[15] Maguire, J.D. (1962) Speed of germination aid in selection and evaluation for seedling emergence and vigour. Crop Science, 2, 176-177. doi:10.2135/cropsci1962.0011183X000200020033x

[16] Kotowski, F. (1962) Temperature relations to germination of vegetable seeds. Proceedings of American Society of Horticultural Science, 23, 176-177.

[17] Srivastava, A.K. and Sareen, K. (1974) Physiology and biochemistry of deterioration of soybean seeds during storage. Plant Horticulturae, 7, 545-547.

[18] Lowry, O.H., Rosebrough, N.T., Farr, A.L. and Randall, R.J. (1951) Protein measurement with folin phenol reagent. Journal of Biological Chemistry, 193, 265-275.

[19] Sadasivam, S. and Manickam, A. (2005) Biochemical methods. 2nd Edition, New age International, New Delhi.

[20] Penner, D. and Ashton, F.M. (1967) Hormonal control of protease activity in squash cotyledon. Plant Physiology, 42, 791-796. doi:10.1104/pp.42.6.791

[21] Riley, J.M. (1987) Gibberellic acid for fruit set and germination. CRFG Journal, 19, 10-12.

[22] Jamil, M. and Rha, E.S. (2007) Gibberellic acid (GA) enhances seed-Water uptake, germination and early seedling growth in sugar beet under salt stress. Pakistan Journal of Biological Science, 4, 654-658.

[23] Cherif, M., Tirilly, Y. and Belanger, R.R. (1997) Effect of oxygen concentration on plant growth, lipid peroxidation and receptivity of tomato roots to Pythium F 707 under hydroponic conditions. European Journal of Plant Pathology, 103, 225-264. doi:10.1023/A:1008691226213

[24] Ashton, F.M. (1976) Mobilization of storage proteins of seeds. Annual Review of Plant Physiology, 26, 95-117. doi:10.1146/annurev.pp.27.060176.000523

[25] Misra, N.M. and Kar, R.K. (1990) Regulation of storage protein degradation in cotyledons of germinating cowpea. Indian Journal of Plant Physiology, 33, 333-330.

[26] Muhyaddin, T. and Wiebe, H.J. (1989) Effect of seed treatments with polyethylene glycol (PEG) on emergence of vegetable crops. Seed Science Technology, 17, 49-56.

[27] Willumsen, J. and Roeber, R.U. (1997) Improvements of the physical conditions in peat substrates during the germination of cabbage seeds in organic farming. Proceedings of International Symposium on Growing media and Plant nutrition in Horticulture, Acta-Horticulturae, 450, 183-190. 
[28] Patil, N.A., Chavan, S.J. and Desai, N. (2005) Soil aeration: An eco-friendly technological innovation for soil conditioning, leading to higher yield. Proceedings of $\mathrm{Na}$ - tional Conference on Plant Diversity and Biotechnology, 10-11 December, 2004, P. R. Ghogrey Science College, Dhule (M.S.) India, 262-270. 